mendations." PS: Political Science \& Politics 25 (3):547-54

Feldman, K.A. 1992. "College Students' Views of Male and Female College Teachers: Part I-Evidence from the Social Laboratory and Experiments." Research in Higher Education 33:317-75.

Feldman, K.A. 1993. "College Students' Views of Male and Female College Teachers: Part II-Evidence from Students' Evaluations of Their Classroom Teachers." Research in Higher Education 34:151-211.

Freeman, H.R. 1994. "Student Evaluations of College Instructors: Effects of Type of Course Taught, Instructor Gender and Gender Role, and Student Gender". Journal of Educational Psychology 86:627-30.

Goodwin, L.D. and E.A. Stevens. 1993. "The Influence of Gender on University Faculty Members' Perceptions of 'Good Teaching.' " Journal of Higher Education 64:16685 .

Grigel, F. and S. Goldenberg. 1988. "Sex Characteristic Stereotypes or Congruence: Do Either Matter Any More to Ratings of Performance." Intemational Joumal of Comparative Sociology 29:245-51.

Kierstad, D., P. D'Agnostino and H. Dill. 1988. "Sex Role Stereotyping of College
Professors: Bias in Student Ratings of Instructors." Journal of Educational Psychology 80:342-44.

Langbein, L.I. 1994. "The Validity of Student Evaluations of Teaching." PS Political Science \& Politics 27 (3):545-53.

Marsh, H.W. 1984. "Students' Evaluations of University Teaching: Dimensionality, Reliability, and Validity, Potential Biases, and Utility." Joumal of Educational Psychology 76:707-54.

Martin, E. 1984. "Power and Authority in the Classroom: Sexist Stereotypes in Teaching Evaluations." Signs 9:483-92.

McKeachie, W.J. 1990. "Research on College Teaching: The Historical Background." Journal of Educational Psychology 82:189 200.

Murray, H.G., J.P. Rushton, and S.V. Paunonen. 1990. "Teacher Personality Traits and Student Instructional Ratings in Six Types of University Courses." Journal of Educational Psychology 82:250-61.

Sandler, B.R. 1991. "Women Faculty at Work in the Classroom, or, Why It Still Hurts to Be a Woman in Labor." Washington, DC: Center for Women Policy Studies.

Sidanius, J. and M. Crane. 1989. "Job Evaluation and Gender: The Case of University
Faculty." Joumal of Applied Social Psychology 19:174-97.

Statham, A., L. Richardson and J. Cook. 1991. Gender and University Teaching: $A$ Negotiated Difference. Albany: SUNY Press.

Tatro, C.N. 1995. "Gender Effects of Student Evaluations of Faculty." Journal of Research and Development in Education 28: 169-73.

Zenoff, E.H. and K.V. Lorio. 1983. "What We Know, What We Think We Know, and What We Don't Know About Women Law Professors." Arizona Law Review 25:869905.

\section{About the Authors}

Kristi Andersen is professor and chair of the political science department in the Maxwell School, Syracuse University. Elizabeth D. Miller is a student in the MPA program in the department of public administration in the Maxwell School. This article was prepared in consultation with the members of the Committee on the Status of Women in the Profession.

\title{
The Status of African American Faculty in Political Science Departments in the Southern Region
}

\author{
Shirley Tolliver Geiger, Savannah State University \\ Toni-Michelle Travis, George Mason University
}

\begin{abstract}
Editor's Note: A report titled "The Status of African American Faculty in Political Science Departments in the Southern Region" was presented to the Executive Council of the Southern Political Science Association at the Annual Meeting of the Southern Political Science Association in Atlanta, November 5, 1996. The Report was written by Shirley Tolliver Geiger of Savannah State University and Toni-Michelle Travis of George Mason University, cochairs of the Association's Committee on the Status of Blacks in the Discipline. Questions regarding this report should be directed to Shirley Geiger, Master of Public Administration Program, Savannah State University, Savannah, GA 31404 or e-mail: geigers@tigerpaw.ssc.peachnet.edu. Copies of the full report, with description of survey methodology, data, twelve tables, and references can be obtained from Dr. Geiger. Only the "Introduction" and "Conclusions" sections of the 30-page report are included here. $A$ copy of the full report is also avail-
\end{abstract}

\begin{abstract}
able on the SPSA web page at http:// www.olemiss.edu/orgs/spsa.
\end{abstract}

\section{Introduction}

This report examines the status of African American faculty in political science programs in the 16-states that constitute the APSA's southern region where roughly one quarter $(n=325)$ of the nation's degreegranting political science programs are located. Over half of the country's African Americans (58\%) live in the region, and today African Americans account for an average of $25 \%$ of the college-aged population in 12 of the southern states. The region's racial demographics take on particular significance in light of the conclusions of a report by the Southern Education Foundation that, some 40 years after the Supreme Court's ruling in Brown v. Topeka (1954) and one hundred years after
Plessy v. Ferguson (1896), "substantial remnants of segregation continue to shape higher education [in the southern region]" (SEF, 1996, p. xv). Even after the passage of the Civil Rights Act of 1964 and the federal court ruling in Adams v. Richardson (1973), lack of racial/ethnic diversity among faculty and students is one of the most intractable remnants of the legally segregated dual educational systems.

African American college students are still under-represented in the South's traditionally White post-secondary institutions (TWI), but the shortage of African American faculty is equally, if not more profoundly, acute in every institution and in every state (SEF, 1995). With specific reference to political science departments, Preston and Woodard (1990, 37) use the term "disquieting" to describe the low number of Black faculty across the country. The find- 
ings reported here suggest that the same observation could be made of the southern region.

\section{Recommendations and Conclusions}

This section lists some of the recommendations for increasing the number of African Americans in the profession that emerged in interviews with Black faculty.

\section{Expand the Graduate "Pipeline"}

Increasing the number of African Americans in the professoriate begins with the production of African American political science doctoral candidates. There is considerable evidence of a decline in the percentage of African American PhD candidates in political science since the late 1970s. Brintnall's (1992) data show a drop from 424 in 1980 to 300 in 1991. Such a decline has obvious implications for the pool of African American political scientists. African Americans are $8.4 \%$ of PhD students, $23 \%$ of master of public administration students, and $16.8 \%$ of master's of political science students. African Americans received $9.3 \%$ of $\mathrm{PhDs}$ earned in the southern region in the past five years, and African American women earned about half of the political science PhDs granted to African Americans.

With African Americans comprising nearly $11 \%$ of students leaving PhD programs before completing, but under $9 \%$ of all students, the drop out rate for African Americans is disproportionately high. The most commonly cited reason for African Americans leaving is failure to pass comprehensives (33\%), compared to 20 percent of Whites who leave for that reason. Thus, with African American PhD students, as with faculty, the issue of retention looms large. No survey of African American $\mathrm{PhD}$ students in political science is available to provide the insider's view of what is happening to students in the $\mathrm{PhD}$ programs, but such an examination might help $\mathrm{PhD}$ programs better understand what they need to do to attract some of the best young African American stu- dents to graduate study. Such information might help them make a sincere effort to retain and develop those they admit. Further, given the split of African American political science majors between historically Black colleges (44\%) and traditionally White colleges $(56 \%)$ in this survey, it is imperative that graduate programs in TWI graduate programs collaborate with HBCUs and other TWIs to help them nurture students with potential from their freshman year forward. Simply recruiting African American students in the senior year is not likely to yield positive results because students may miss important opportunities to improve their computational, reading, and writing skills necessary for successful graduate study. Or, the best students may be fully committed to law school by that point. Efforts such as the APSA Summer Program for juniors should be supported and emulated by $\mathrm{PhD}$ programs throughout the southern region, beginning at an even earlier point in the student's career.

\section{Tap the Existing Pool}

For the department seeking to recruit African Americans from the existing pool, additional efforts are necessary to attract candidates. Salary, geographic locale, and the presence of African Americans in the surrounding community rank high in candidates's considerations. Since location and population composition are beyond the control of the department, sincerity, salary, and other factors become more important.

\section{Search Seriously}

As noted above, departments should use multiple communications channels to identify and notify African American faculty of openings. The successful departments use a variety of media and establish their own network by telephone calls, mailings, and the like.

\section{Be Sincere}

Faculty interviewed say departments demonstrate sincerity by showing respect for African Ameri- can candidates and an appreciation of their needs, concerns, and strengths. Black faculty ask: Does the department have a reputation for hiring African American faculty only in affirmative action lines? Does it have a history of providing a hostile and/or neglectful climate for African American faculty and graduate students? Is there an on-going formal support system to promote the growth and progress of all non-tenured faculty? Is research on race by an African American less respected than that of an Anglo scholar? Is finding someone to fit the specific job description more important than finding a job to fit a strong African American candidate?

\section{Use Flexible Job Descriptions}

The frequently cited explanation for the dearth of African American hires is the failure of African American candidates to match the job description. A sincere commitment to affirmative action might prompt a discussion of flexibility on job description or a willingness to offer up-front retraining to enable the strongest African American to meet the department's specific needs, or adapting to the strengths of the candidate.

\section{Know Backgrounds of Potential Applicants}

Another finding of this study points to the success of schools in the southern region in recruiting southerners. Over 80 percent of the African American junior faculty interviewed were born in the South and, except for one, each is now teaching at an institution in their native state. Thus, the data show a willingness of African Americans to seek employment in their home states, and institutions may benefit from this. On the other hand, that finding points to two other problems. One is that it is may be difficult to get non-southern African Americans to seek positions in the region and two, that southern African Americans may not be aggressively seeking positions outside their home state. The first situation may result from the South's image, and the second, 
from African American's tendency to seek positions near friends and family. Finally, White institutions in the South can do more to alter northern African American's perceptions of the region as a place to live and work.

\section{Retain and Nurture Faculty Recruited}

Mentoring Matters. Interestingly, while a considerable body of literature points to the importance of mentors to the success of junior faculty, $75 \%$ of those interviewed had no mentor assigned when they were hired, and one of the two with mentors did not get that mentor until the second year of the appointment. The junior faculty indicated that the mentor relationship must reward the mentor, and hold him/her responsible by linking the mentor's success to the mentee's success. Black senior faculty seem to be making themselves available to help junior African American faculty, as $78 \%$ report receiving some or a lot of help from Black colleagues in the profession. In a number of cases, undergraduate and graduate faculty were also cited as being helpful and encouraging to Black scholars.

Adjust the Environment to the Faculty Member's Needs. Some observers suggest that to attract and retain under-represented groups, including women (of all ethnic groups) and African American and Hispanic men, in particular, university environments must do more to ensure their job satisfaction and success (Patten 1996). In addition to the usual approaches (competitive salaries, sabbaticals, released time for research, and family leave provisions), Tack and Paitu (1992) recommend that universities also consider allowing greater flexibility in promotion and tenure schedules to assure tenure and promotion through the ranks.

Focus on strengths and value-added. Finally, Van Patten $(1996,7)$ suggests that with regard to retention, an "effective operating model is to be supportive of colleagues, build up their achievements, and assist them in their goals whenever and however possible." He also recommends that efforts be made to reward faculty on the basis of their strengths and val- ue-added to the department or program, rather than focusing on weaknesses. Indeed, Van Patten's prescription may be good for the morale of all faculty, not just African Americans.

While affirmative action programs may be out of favor in some circles, it is clear that the goal of diversifying the faculty has not been achieved in the southern region. As political science departments note the decline in student enrollment in political science programs generally, practical considerations, if no other, may cause renewed attention to issues of diversity, given the relationship between the presence of same race faculty and student majors. Further, the study points to the gaps in our knowledge of what is happening with African American graduate students in political science programs, the key to ensuring the availability of new faculty. Finally, the statistics on the large percentage of untenured African American political science faculty suggests that retention issues must be on the agenda of departments serious about maintaining some semblance of diversity. 